\title{
Top incomes and the gender divide
}

\author{
Working paper 5
}

September 2016

\author{
A. B. Atkinson, A. Casarico and S. Voitchovsky \\ In co-operation with F. Alvaredo, J. Modalsli and J. Søgaard
}

Keywords: top income groups, gender, income composition

Link to working paper:

http://eprints.Ise.ac.uk/101814/1/Atkinson Voitchovsky Casarico top incomes and the gender divide wp5.pdf

More on the theme of \#LSEWealth

Raising inequality is a global challenge and primary policy concern. Research on top incomes has shown how, in many countries, there have been significant increases in the shares of total income accruing to those at the top in recent decades, indicating an increase in the concentration of incomes. In this work we first ask a simple question - how many of those in the top income groups are women? The gender composition of the top income group has been surprisingly little investigated. There is a strong suspicion that women are underrepresented, but a shortage of hard evidence. Whatever one thinks about the share of income accruing to the top one per cent, if women are seriously under-represented, then this raises questions about the fairness of the economic system. Little too is known about whether the gender divide has been narrowing over time: the dynamics in the share of women at the top is, thus, the second issue we turn to. The analysis of the evolution of female representation in the top deciles brings up two further questions: is the pattern of under-representation of women that we identify at the very top evidence of a "glass ceiling" for incomes? And does the composition of income play a role in explaining the pattern of female representation at the top? In this research we address these questions and contribute to build evidence on women and top incomes.

While a lot is known about gender differentials in earnings, the presence, the extent and the dynamics of gender inequality in total incomes -which include also self-employed income and income from capital- is much less investigated. Self-employment and capital income are particularly important sources at the top of the distribution and they may change the gender inequality picture. Equal pay and laws outlawing discrimination in employment do not apply to the self-employed, where women may also be disadvantaged. There is evidence that in some countries women have in the past owned a significant fraction of total wealth and hence have received a significant share of capital income. What has happened to capital income over time is thus likely to change the picture of gender inequality and worth investigating. 
To explore the gender divide at the top of the distribution, we use tax record data for eight countries with individual taxation (Australia, Canada, Denmark, Italy, New Zealand, Norway, Spain and the UK). We work with an unbalanced sample over the period 1980-2015, with information on Canada and New-Zealand going back to the Forties and Fifties, respectively. We find that women are strongly under-represented at the top of the distribution in all eight countries considered. Women account for under a quarter of those in the top $1 \%$ of incomes. Although the presence of women at the top has increased over time, the rise becomes smaller at the very top, which signals the presence of a glass ceiling in total incomes. For instance, in Italy and the UK, there is little sign of an increase in women's representation in the top $0.1 \%$ over the last fifteen years. The income composition differs by gender, with capital income playing a more salient role for women, and exhibits significant changes over time, underlining the fact that it is not sufficient to look only at earned income to investigate gender inequality. We discuss the role of demographics, both in terms of ageing and mating patterns, changes in the tax structure, in female labour force participation and in wealth holding as potential explanations for the changing composition of income and for how these changes feed into the dynamics of female presence at the top. Overall, the evidence gathered complements our knowledge on gender disparities and lays the ground work for future research into the causes of gender inequality and into the policies which can address it.

\section{LSE International Inequalities Institute}

The International Inequalities Institute (III) based at the London School of Economics and Political Science (LSE) aims to be the world's leading centre for interdisciplinary research on inequalities and create real impact through policy solutions that tackle the issue. The Institute provides a genuinely interdisciplinary forum unlike any other, bringing together expertise from across the School and drawing on the thinking of experts from every continent across the globe to produce high quality research and innovation in the field of inequalities.

In addition to our working papers series all these these publications are available to download free from our website: www.lse.ac.uk/III

For further information on the work of the Institute, please contact the Institute Manager, Liza Ryan at e.ryan@Ise.ac.uk

International Inequalities Institute

The London School of Economics and Political Science

Houghton Street

London

WC2A 2AE

Email: Inequalities.institute@Ise.ac.uk 
Web site: www.Ise.ac.uk/III

@ @LEInequalities

(c) A. B. Atkinson, A. Casarico and S. Voitchovsky. All rights reserved.

Short sections of text, not to exceed two paragraphs, may be quoted without explicit permission provided that full credit, including $\odot$ notice, is given to the source.

THE LONDON SCHOOL

OF ECONOMICS AND

POLITICAL SCIENCE

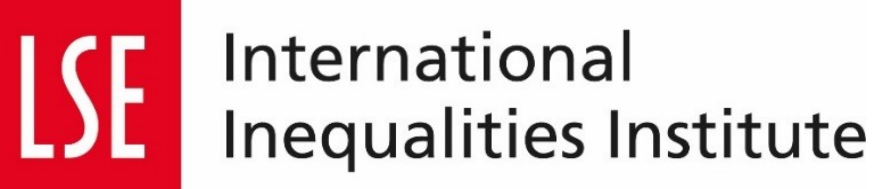

